\title{
Application of Spent lon Exchange Sorbents for the Reclamation of Degraded Soils
}

\author{
Mariola Chomczyńska', Henryk Wasag ${ }^{1}$, Justyna Kujawska ${ }^{1 *}$ \\ ${ }^{1}$ Faculty of Environmetal Engineerig, Lublin University of Technology, ul. Nadbystrzycka 40B, 20-618 Lublin, \\ Poland \\ * Corresponding author's e-mail: j.kujawska@pollub.pl
}

\begin{abstract}
The paper presents the possibility of applying spent synthetic ion exchangers and sorbents based on natural zeolites for the reclamation of degraded soils. The obtained research results confirmed the improvement of the soil sorption capacity (cation exchange capacity) caused by the addition of spent ion exchange sorbents. They also enabled to determine the magnitude of changes of the analyzed parameters depending on the amount of wastes introduced to the soil. The addition of $1 \%(\mathrm{w} / \mathrm{w})$ spent cation exchanger enables to increase the cation exchange capacity twice, whereas in the case of zeolite, the observed increase reaches about $20 \%$. Simultaneously, introduction of waste ion exchange sorbents increases the content of exchangeable calcium and magnesium while doubling in the content of these macroelements is observed for $5 \%(\mathrm{w} / \mathrm{w})$ and $2 \%(\mathrm{w} / \mathrm{w})$ of spent ion exchanger, respectively. In the case of the exchangeable potassium content, a satisfactory increase is observed with $1 \%(\mathrm{w} / \mathrm{w})$ addition of spent zeolite.
\end{abstract}

Keywords: degraded soils, ion exchange sorbents, cation exchange capacity

\section{INTRODUCTION}

Development of human civilization contributes to the on-going degradation of soils. It is estimated that about $24 \%$ of global land area has been affectted by degradation [D'Odorico et.al. 2016]. At present, the area of degraded lands in Poland amounts to 64651 ha, which corresponds to $0.21 \%$ of the country area [CSO 2017]. The disruption of primary soil properties on degraded areas is diversified and indicates the actions which should be taken as part of technical and biological reclamation, in order to restore the use value to the degraded areas [Maciak 1999, Osman, 2014]. The technical reclamation involves shaping the topography, regulating the hydrographic conditions, building infrastructure and sometimes recreating soil by adding and binding fertile soil with a layer of reclaimed land. The biological reclamation includes cultivation of appropriate plant mixes in order to create humus, as well as planting adequate species of trees, bushes and perennial plants on escarpments and slopes to protect them against erosion [Bing-Yuan and Li-Xun, 2014].
The degradation process of soils is often accompanied by the deterioration of their sorption properties, regulated by the colloidal solid phase called the soil sorption complex. Deterioration of the afore-mentioned properties occurs as a consequence of erosion process, inappropriate agricultural practices, or devastation or disruption of the soil humic level in the residential and industrial areas as well as during road constructions [Sheoran et al., 2010; Siuta 1998]. The sorption properties of soils are extremely important to ensure the adequate growth and development conditions for plants. The sorption complex significantly limits the leaching of nutrients from soils and regulates the concentration of the soil solution after the introduction of fertilizers, thus preventing the damage of plant roots. Moreover, the components of the sorption complex are partly responsible for the buffer capacity of soils, which prevents rapid changes in the $\mathrm{pH}$ [Lityński and Jurkowska 1982; Zhang et al., 2016]. Improvement of the sorption properties or their complete restoration on degraded areas is carried out using suitable materials, which include i.a. peats, composts, sewage sludge, 
weathered bentonite [Karczewska 2008; Karczewska et al., 2004; Sheoran et al., 2010]. The above-mentioned range of materials can be expanded with production wastes or spent materials employed in numerous processes. The possibility of applying spent ion exchange sorbents for the improvement of sorption properties of degraded or fallow soils seems to be a logical consequence of their properties. However, there is a threat related to the pollution of the environment with the toxic substances that may be contained in wastes.

The type, quality and quantity of wastes which may be employed for soil reclamation are described in detail in legal regulations (Regulation of the Minister of Environment of 11 May 2015 on recovery of waste outside the installations and facilities [Journal of Laws, 2015, item 796]). In the waste accepted for processing on surface providing benefits for agriculture or improvement of environmental conditions i.e. so-called recycling process R10, indicated in polish regulation, spent ion exchange sorbents are not included [Journal of Laws of 2015, item 132]. This is understandable in connection with the wastes from wastewater treatment processes. However, a substantial amount of spent ion exchange sorbents is connected with water treatment processes, and in such cases, these wastes are not hazardous to the environment. The disposal of such wastes cannot, and should not, solely involve deposition on landfills [Leboda et al., 2003]. Environmental protection requires seeking new and efficient methods of solving the issues of waste management. The application of wastes in the way that does not harm the environment with a simultaneous minimization of energy consumption, human labor and required land area should be a priority [Kyncl et al., 2012]. The legal regulations ensuring the broadly understood environmental protection should not hinder the realization of such approach, while the search for new waste applications should be considered one of the integral elements of environmental protection.

\section{MATERIALS AND METHODS}

Spent, strong acidic Wofatit KPS cation exchanger, spent natural zeolite and two soils having low projected exchange capacity were used in the study. Cation exchanger was collected from the water treatment plant in a former car factory in Lublin. Zeolite was obtained from a water treatment plant in Dys (located in the vicinity of Lublin) and originally came from the Sokirnica deposit located in the Zakarpattia Oblast in Ukraine. The main component of the zeolite material is clinoptilolite $(70-75 \%)$. The first of the soils used in the study was taken from the edge of sand mine excavation in Rokitno. The second was collected from the fallow land adjacent to the Zemborzycki lake. The laser diffraction grain size analysis was carried out for the soil samples [Ryżak et al., 2009]. The results of this analysis indicated that both soils should be classified as loamy sand (Table 1).

In order to carry out the research, it was necessary to prepare the mixtures based on the materials characterized above. The applied additions of ion exchange sorbents to soils amounted to $1 \%, 2 \%$, and $5 \%(\mathrm{w} / \mathrm{w})$, respectively. Separate additions of both sorbents were introduced to the degraded soils, whereas in the case of fallow soil, only the addition of spent zeolite was applied. Thy hydrolytic acidity and the content of alkaline cations: $\mathrm{Ca}^{2+}, \mathrm{Mg}^{2+}, \mathrm{K}^{+}$and $\mathrm{Na}^{+}$were determined for particular sorbents, soils and their mixtures. The hydrolytic acidity was determined after treating the samples with calcium acetate solution with the $\mathrm{pH}=8.2$. The resultant acetic acid was titrated with $0.1 \mathrm{M}$ solution of $\mathrm{NaOH}$. The content of alkaline cations was determined following their leaching from samples by means of subsequent doses of $1 \mathrm{M}$ solution of ammonium acetate with the $\mathrm{pH}=7$ [Ostrowska et al., 1991]. In the obtained eluates, the concentrations of cations were determined by means of inductively coupled plasma atomic emission spectrometry (Ultrace

Table 1. Grain size distribution of soils

\begin{tabular}{|l|c|c|c|c|c|c|c|c|c|}
\hline \multirow{3}{*}{ Soil } & \multicolumn{7}{|c|}{ Fraction content in \% } & \multicolumn{4}{c|}{ dust } & loam \\
\cline { 2 - 10 } & \multicolumn{9}{|c|}{ sand } \\
\cline { 2 - 10 } & $\begin{array}{c}2.0-1.0 \\
\mathrm{~mm}\end{array}$ & $\begin{array}{c}1.0-0.5 \\
\mathrm{~mm}\end{array}$ & $\begin{array}{c}0.5-0.25 \\
\mathrm{~mm}\end{array}$ & $\begin{array}{c}0.25-0.10 \\
\mathrm{~mm}\end{array}$ & $\begin{array}{c}0.10-0.05 \\
\mathrm{~mm}\end{array}$ & $\begin{array}{c}0.05-0.02 \\
\mathrm{~mm}\end{array}$ & $\begin{array}{c}0.02-0.005 \\
\mathrm{~mm}\end{array}$ & $\begin{array}{c}0.005- \\
0.002 \mathrm{~mm}\end{array}$ & $\begin{array}{c}<0.002 \\
\mathrm{~mm}\end{array}$ \\
\hline $\begin{array}{l}\text { Degraded soil } \\
\text { (Rokitno) }\end{array}$ & 3.37 & 25.96 & 27.79 & 9.45 & 7.17 & 13.50 & 8.56 & 2.28 & 1.92 \\
\hline $\begin{array}{l}\text { Fallow soil (Zalew } \\
\text { Zemborzycki) }\end{array}$ & 0.32 & 23.49 & 39.14 & 11.16 & 5.44 & 10.35 & 6.75 & 1.93 & 1.42 \\
\hline
\end{tabular}


238 Jobin Yvon). The data obtained following calculation per mass unit $(\mathrm{cmol}(+) / \mathrm{kg})$ were used to determine the cation exchange capacity (sorption capacity) employing the following formula [Myślińska, 2010]:

$$
C E C=S+H_{h}
$$

where: $C E C$ - cation exchange capacity (sorption capacity for cations),

$S$ - sum of alkaline exchangeable cations, $H_{h}$ - hydrolytic acidity (content of hydrogen and aluminum ions).

\section{RESULTS AND DISCUSSION}

The soils used in the research were characterized by weak sorption properties, which often deteriorate as a result of degradation processes. The sorption capacity of degraded soil amounted to $6.93 \mathrm{cmol}(+) / \mathrm{kg}$, while for fallow soil, this parameter was lower and equalled $5.83 \mathrm{cmol}(+) / \mathrm{kg}$. Comparing the above-mentioned sorption capacity values with the reference values reported by Lityński, the examined soil samples can be included to moderate, or even high class [Zawadzki, 1999]. However, according to other CEC reference values the sorption capacities of the considered soils are characteristic for low or even very low class (Table 2) [Martin and Nolin, 1992; European Soil Bureau].

It seems logical that the values of soil sorption capacity could be improved using the additions of ion exchange sorbents. This is confirmed by the obtained results of the research conducted using spent cation exchanger and zeolite, for which the determined cation exchange capacities amounted to 397 and $118 \mathrm{cmol}(+) / \mathrm{kg}$, respectively. The data in Figure 1 indicate that both the addition of a natural sorbent, as well as a synthetic ion exchanger, contribute to an increase in the cation exchange capacity. The observed increases depend on the type and dose of the utilized ion exchange sorbent. In the case of introducing spent cation exchanger in the amount of $1 \%(\mathrm{w} / \mathrm{w})$ to degraded soil, an increase in the capacity is observed up to $12 \mathrm{cmol}(+) / \mathrm{kg}$, whereas a $5 \%$ addition enables to achieve the value of $27.3 \mathrm{cmol}(+) / \mathrm{kg}$. It should be noted that the increasing values of cation exchange capacity form a linear dependency on the amount of introduced ion exchanger. Less spectacular increases in the cation exchange capacity were noted in the case of natural zeolite addition, although the observed capacity values also form a linear dependency in the function of the amount of added sorbent (Fig. 1). For a degraded soil, a $1 \%(\mathrm{w} / \mathrm{w})$ addition of zeolite enables to achieve approximately $25 \%$ increase in the sorption capacity, while a $5 \%$ addition is tantamount to a doubling of this value. The data in Figure 1 shows that similar increases are noted for the soil originating from fallow land. In this case, a $1 \%$ zeolite addition to soil resulted in a $20 \%$ increase in the cation exchange capacity, a $2 \%$ addition - approximately in a $40 \%$ increase, while a $5 \%$ addition, in line with the observed linear dependency, nearly doubled the CEC value (Fig. 1). While assessing the obtained increases in the sorption capacity and comparing them to the reference values in table 2 it can be stated that a moderate addition of the ion exchange sorbent enables to improve the sorption capacity to the levels characteristic for the soils with satisfactory sorption properties. Simultaneously, the addition of spent ion exchange sorbents contributes to an increase in the content of available macronutrients. The data in Figure 2 indicates that the addition of synthetic cation exchanger to the degraded soil significantly increases the content of exchangeable calcium and magnesium. The observed increasing contents of these macroelements also assume linear dependencies on the amount of cation exchanger addition introduced to soil. For instance, degraded soil containing about $5 \mathrm{cmol}(+) / \mathrm{kg}$ of calcium

Table 2. Definition of CEC classes

\begin{tabular}{|l|c|c|c|}
\hline \multirow{2}{*}{ CEC class } & \multicolumn{3}{|c|}{ CEC [cmol(+)/kg] according to: } \\
\cline { 2 - 4 } & Martin and Nolin & European Soil Bureau & Lityński \\
\hline Very low & $<6$ & - & $3.5-4.5$ \\
\hline Low & $6-12$ & $<15$ & $4.6-6.5$ \\
\hline Moderate & $12-25$ & $15-40$ & $6.6-7.5$ \\
\hline High & $25-40$ & $>40$ & $7.6-9.0$ \\
\hline Very high & $>40$ & - & $>9.0$ \\
\hline Extremely high & - & - & \\
\hline
\end{tabular}


after the introduction of $1 \%$ ion exchanger addition, reaches the value of $6.8 \mathrm{cmol}(+) / \mathrm{kg}$, while with $5 \%$ addition, the observed value increases to $8.8 \mathrm{cmol}(+) / \mathrm{kg}$ (Fig. 2). Even greater improvement is observed in the case of the magnesium content along with the increasing doses of the ion exchanger. A $2 \%(\mathrm{w} / \mathrm{w})$ ion exchanger addition is sufficient to increase the content of exchangeable magnesium more than twice.

The content of exchangeable $\mathrm{K}$ in substrates is important from the point of view of soil fertility and potassium supply for plants [Kaminski, at al., 2009]. The soils used in the study were characterized by a relatively low content of exchangeable potassium in the range of $0.12-0.14 \mathrm{cmol}(+) / \mathrm{kg}$ (Fig. 3), which is a typical value for the soils characterized by low fertility, classified as loose sand in terms of the grain size analysis. Introducing even a small amount of spent zeolite sorbent enables to increase the amount of exchangeable potassium to the levels characteristic of fertile soils [Fotyma, 2007]. Such level can be achieved by utilizing a $2 \%(\mathrm{w} / \mathrm{w})$ zeolite addition, owing to which the observed contents of exchangeable potassium in degraded soil and the soil from fallow land amount to 0.68 and $0.67 \mathrm{cmol}(+) / \mathrm{kg}$, respectively (Fig. 3). From the point of view of increased exchangeable potassium content in soil, even lower additions (about 1\%) are capable of improving this parameter to a satisfactory level. As indicated in the research results, applying spent ion exchange sorbents in the amounts greater than $2 \%$, despite their contribution to spectacular $\mathrm{K}$ content increase, seems to be unjustified in practical terms.

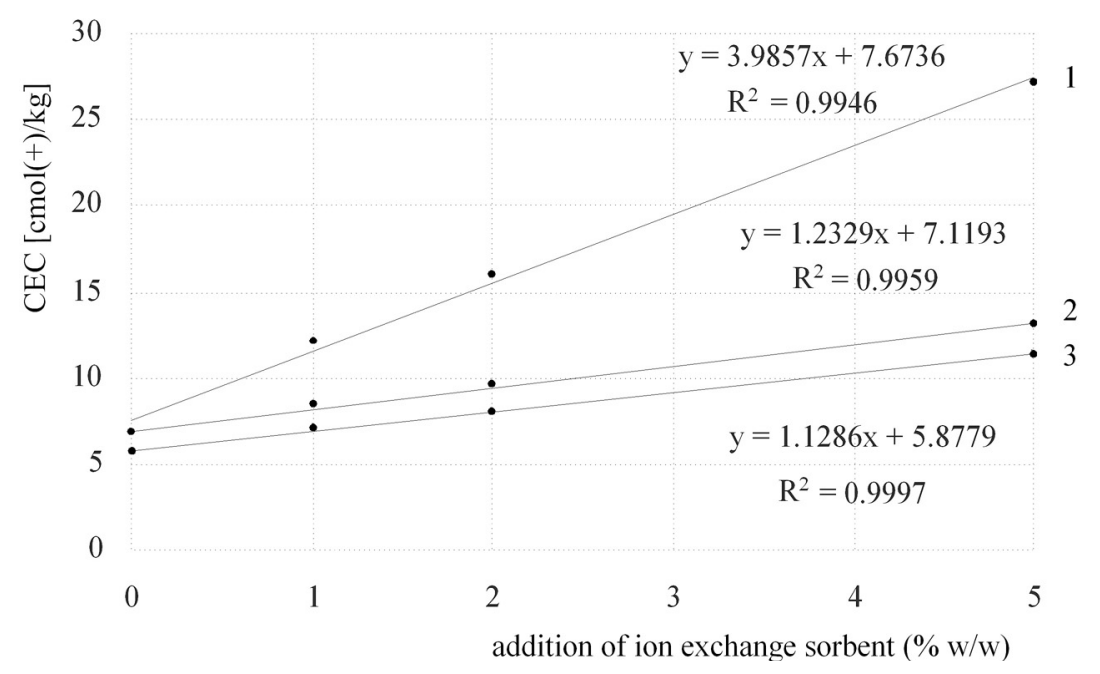

Figure 1. Influence of ion exchange sorbent addition on the changes of soil cation exchange capacity $(1-$ degraded soil + resin, 2 - degraded soil + zeolite, 3 - fallow soil + zeolite $)$

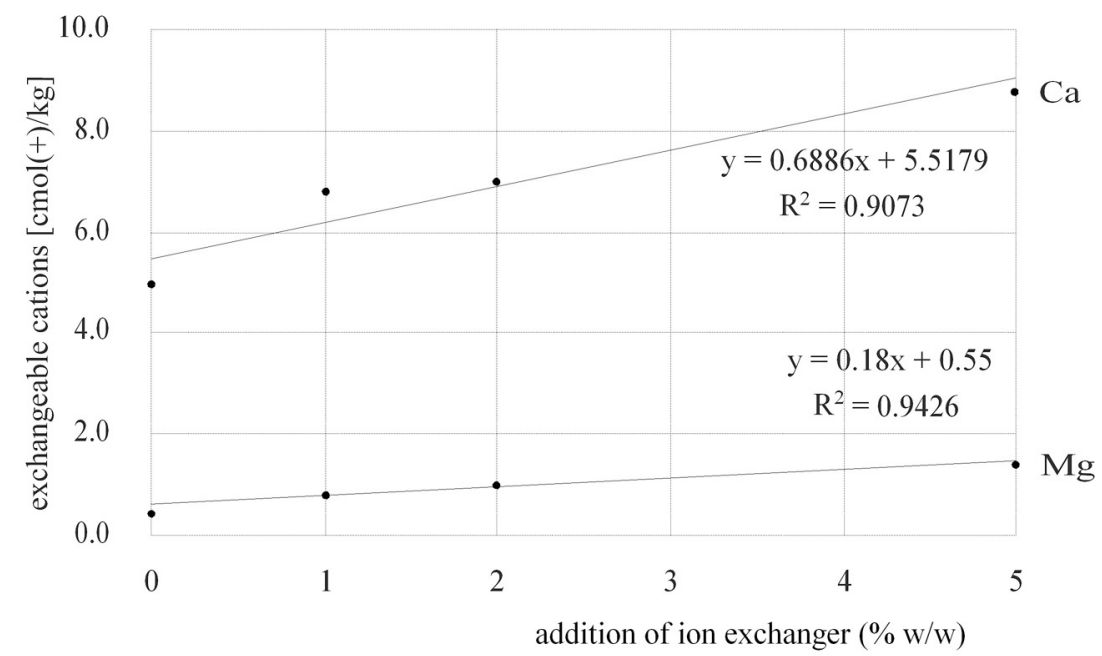

Figure 2. Changes in the content of exchangeable calcium and magnesium in degraded soil depending on the dose of spent cation exchanger 


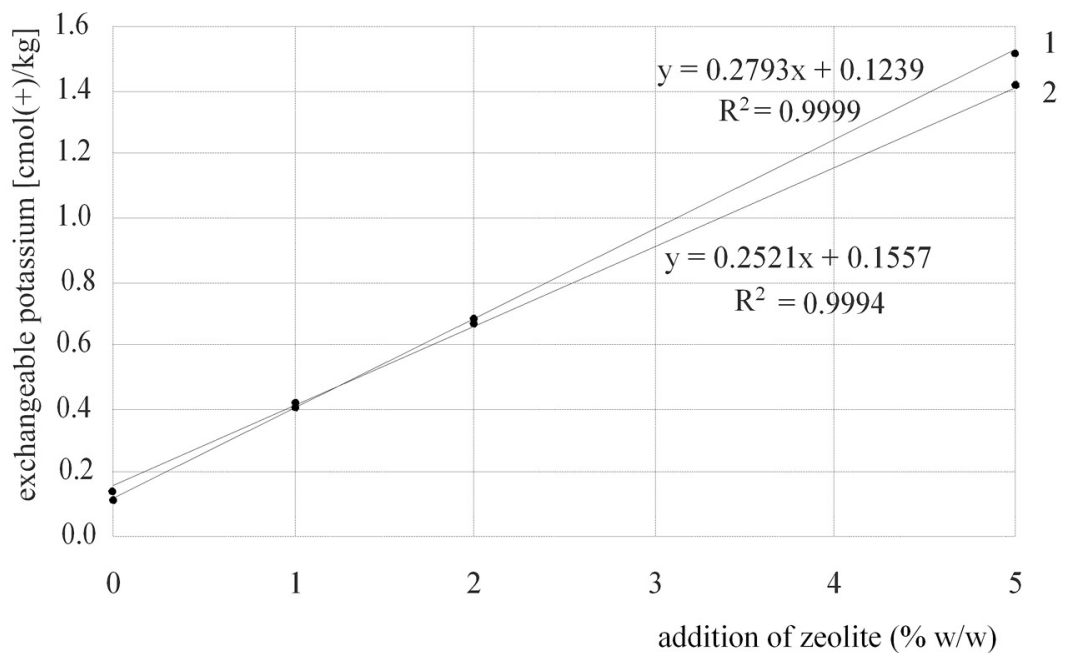

Figure 3. Changes in the exchangeable potassium content in soil depending on the amount of introduced spent zeolite ( 1 - degraded soil, 2 - fallow soil)

\section{CONCLUSIONS}

The addition of spent ion exchange sorbents enables to reduce the degree of soil degradation reflected in the decrease in the cation exchange capacity. The observed increases of this parameter are dependent on the type of the utilized ion exchange sorbent and its dose. In the case of introducing $1 \%(\mathrm{w} / \mathrm{w})$ of spent cation exchanger to degraded soil, a doubling in the cation exchange capacity is observed, both for the degraded and fallow soil. Higher additions of spent ion exchanger enable to raise this parameter to the levels considered as high ones. The observed changes in the exchange capacity of soils induced by zeolite additions are lower. A 1\% (w/w) addition is tantamount to approximately $20 \%$ increase in the exchange capacity and doubling of this parameter was observed with $5 \%(\mathrm{w} / \mathrm{w})$ spent zeolite addition. Simultaneously, the addition of spent ion exchange sorbents contributes to an increase of available macronutrients in soils. The addition of synthetic cation exchanger to degraded soils enables significant increases in the content of exchangeable calcium and magnesium depending on the applied doses. The content of exchangeable calcium in soils was nearly doubled at $5 \%(\mathrm{w} / \mathrm{w})$ addition of spent ion exchanger, and in the case of exchangeable magnesium, the doubling of its content occured with a $2 \%(\mathrm{w} / \mathrm{w})$ addition. Introducing low amounts of spent zeolite sorbent increases the exchangeable potassium to the values characterizing fertile soils. Therefore, the application of spent ion exchange sorbents in the amount greater than $2 \%(\mathrm{w} / \mathrm{w})$ seems to be practically unjustified, despite contributing to significant increase of the $\mathrm{K}$ content.

To sum up, it should be stated that the additions of spent ion exchange sorbents to degraded soils enable to mitigate their deterioration reflected in a drop of the exchange capacity, and simultaneously contribute to an increase of the exchangeable calcium, magnesium and potassium content in soils.

\section{REFERENCES}

1. Bing-Yuan H. and Kang Li-Xun K. 2014. Mine land reclamation and eco-reconstruction in Shanxi province in mine land reclamation model. The Scientific World Journal 9, 21-30.

2. Central Statistical Office 2017. Environmental Protection 2017, Warsaw (in Polish).

3. D’Odorico P., Sujith Ravi S. 2015. Land degradation and environmental change. John F Shroder (Ed.), Elsevier, 219-228.

4. European Soil Bureau (ESBN). Soil Information System https://esdac.jrc.ec.europa.eu/esbn/ESDB_ Archive/ptrdb/cec_topa3.pdf (23.09.2018)

5. Fotyma M. 2007. Content of potassium in different forms in the soils of southeast Poland. Polish Journal of Science Soils, XL/1, 19-32.

6. Kaminski J., Moterle D.F., Rheinheimer D.S., Gatiboni C.L., Brunetto G. 2010. Potassium availability in a hapludalf soil under long term fertilization. Revista Brasileira de Ciência do Solo 34(3), 783-791.

7. Karczewska A. 2008. Soil Protection and Recultivation of Degraded Areas. Wroclaw University of 
Environmental. (in Polish).

8. Kyncl M., Č́íhalová S., Juroková M., Langarová S. 2012. Disposal and reuse of the water processing sludge. Journal of the Polish Mineral Engineering Society, 11-20.

9. Leboda R. Skubiszewska-Zięba J., Tomaszewski W., Gun'ko V.M. 2003. Structural and adsorptive properties of activated carbons prepared by carbonization and activation of resins. Journal of Colloid and Interface Science, 263(2), 533-541.

10. Lityński T., Jurkowska H. 1982. Soil fertility and plant nutrition. PWN, Warsaw (in Polish).

11. Maciak F. 1999. Restoration and protection of the environment. Publishing: SGGW, Warsaw (in Polish).

12. Martin A., Nolin M.C. 1992. Étude pédologique du comet de Chambly (Québec). Description et interpretation des unités cartographiqus, Ministre des Approvisionmements et Services Canada.

13. Myślińska E., Laboratory studies of the soils. The University of Warsaw.

14. Osman K.T. 2014. Soil degradation, conservation and remediation 2014th Edition. Springer.

15. Ostrowska A., Gawliński S., Szczubiałka Z. 1991. Methods for analysis and assessment of soil and plant properties. Institute of Environmental Protection, Warsaw (in Polish).
16. Regulation of the Polish Minister of Environment on the R10 recovery process (Journal of Laws of 2015, item 132).

17. Regulation of the Polish Minister of Environment on the recovers of wastes outside of installations and devices (Journal of Laws, 2015, item 796).

18. Ryżak M., Bartmiński P., Bieganowski A. 2009. Methods for determination of particle size distribution of mineral soils. Acta Agrophysica, 175, Institute of Agrophysics, Polish Academy of Science.

19. Sheoran V., Sheoran A.S. and Poonia P. 2010. Soil reclamation of abandoned mine land by revegetation: a review. International Journal of Soil, Sediment and Water, 3, 1-20.

20. Siuta J. 1998. Land Reclamation. The Institute of Environmental Protection, Warsaw (in Polish).

21. Weber J., Karczewska A. 2004. Biogeochemical processes and the role of heavy metals in the soil environment - preface. Geoderma, 122, 105-107.

22. Zawadzki S. 1999. Soil science. PWRiL Warsaw (in Polish).

23. Zhang Y., Zhang W.R., Cai J., Zhang Y., Li H., Huang S. Jiang Y. 2016. Impacts of fertilization practices on $\mathrm{pH}$ and the $\mathrm{pH}$ buffering capacity of calcareous soil. Soil Science and Plant Nutrition, 62(5-6), 432-439. 